\title{
Effect of hydroisostatic compensation depending on the shelf width on the example of the Laptev and the East Siberian seas
}

\author{
Rustam F. Bulgakov* \\ Victor V. Afanas'ev
}

\author{
Institute of Marine Geology and Geophysics, FEB RAS, Yuzhno- \\ Sakhalinsk, Russia \\ *E-mail: r.bulgakov@imgg.ru
}

\begin{abstract}
RUS }}$
Using the method of numerical simulation, we found the nature of the postglacial transgression along the coasts of the Laptev and East Siberian seas to be affected by the shelf width and the continental slope depending on the viscosity properties of mantle layers. In particular, the marks exceeding the contemporary sea level, which are typical for the Holocene climatic optimum of 4-6 ka BP, may be located at different heights. Depending on the area, which fell under the increasing load of the incoming water due to the sea level rise during the postglacial period, and the viscosity of the mantle layers, the earth's surface responds differently to changes in the load and restores its isostatic balance with different rates.
\end{abstract}

\section{Keywords}

postglacial transgression, mantle viscosity, hydroisostasy, vertical movements, Lapteva Sea, East Siberian Sea

For citation Bulgakov R.F., Afanas'ev V.V. Effect of hydroisostatic compensation depending on the shelf width on the example of the Laptev and the East Siberian seas. Geosistemy perehodnykh zon $=$ Geosystems of Transition Zones, 2020, vol. 4, no. 3, pp. 305-320. (In Russ. \& Engl.). https://doi.org/10.30730/gtrz.2020.4.3.305-312.313-320

Для цитирования: Булгаков Р.Ф., Афанасьев В.В. Эффект гидроизостатической компенсации в зависимости от ширины шельфа на примере моря Лаптевых и Восточно-Сибирского моря.

Геосистемы переходных зон, 2020, т. 4, № 3, с. 305-320. https://doi.org/10.30730/gtrz.2020.4.3.305$\underline{312.313-320}$

\section{References}

1. Anisimov M.A., Ivanova V.V., Pushina Z.V., Pitul'ko V.V. 2009. Lagoon sediments of Jokhov Island: age, conditions of formation and meanings for paleogeographic reconstructions of the region of New Siberian Islands. Izvestiia RAN, Ser. Geograficheskaia, 5: 107-119. (In Russ.).

2. Baranskaya A.V. 2015. Rol' noveyshikh vertikal'nykh tektonicheskikh dvizheniy v formirovanii rel'yefa poberezhiy rossiyskoy Arktiki [The role of the latest vertical tectonic movements in formation of the relief of the Russian Arctic coasts]: [Cand. diss. in geographic sciences]. Saint-Petersburg. (In Russ.).

3. Bol'shiyanov D.Yu., Makeyev V.M. 1995. Arkhipelag Severnaya Zemlya. Oledeneniye, istoriya razvitiya prirodnoy sredy [The Severnaya Zemlya Archipelago. Glaciation, history, environment]. Saint-Petersburg: Gidrometeoizdat, 217 p. (In Russ.).

4. Bol'shiyanov D.Yu., Makarov A.S., Shnayder V., Shtof G. 2013. Proiskhozhdeniye i razvitiye del'ty $r$. Leny [Origin and development of the Lena River delta]. Saint-Petersburg: AANII, 268 p. (In Russ.).

5. Clark J., Lingle C. 1979. Predicted relative sea-level changes (18000 Years B.P. to present) caused by Late-Glacial retreat of Antarctic Ice Sheet. Quaternary Research, 11: 279-298. https://doi.org/10.1016/0033-5894(79)90076-0 
6. Clark J., Farrell W., Peltier W. 1978. Global changes in postglacial sea level: Numerical calculations. Quaternary Research, 9(3): 265-287. https://doi.org/10.1016/0033-5894(78)90033-9

7. Fairbridge R. 1961. Eustatic changes in sea level. Physics and Chemistry of the Earth, 4: 99-185. https://doi.org/10.1016/0079-1946(61)90004-0

8. Gavrilov A.V., Romanovskii N.N., Hubberten H.-W. 2006. Paleogeographic scenario of the postglacial transgression on the Laptev Sea shelf. Kriosphera Zemli [Earth cryosphere], 10(1): 39-50. (In Russ.).

9. Kaplin P.A., Selivanov A.O. 1999. Izmeneniye urovnya morey Rossii i razvitiye beregov: proshloye, nastoyashcheye, budushcheye = Sea-level changes and coasts of Russia: past, present, future. Moscow: GEOS, 299 p. (In Russ.).

10. Klemann V., Heim B., Bauch H.A., Wetterich S., Opel T. 2015. Sea-level evolution of Laptev Sea and East Siberian Sea since the last glacial maximum. Arktos, 1: 1(2015). https://doi.org/10.1007/s41063-015-0004-X

11. Makarov A.S. 2017. Kolebaniya urovnya arkticheskikh morey v golotsene [Holocene oscillations in the level of the arctic seas]: [Doctor diss. in geographic sciences]. Saint-Petersburg. (In Russ.).

12. Makarov A.S., Bol'shiyanov D.Yu. 2011. Kolebaniya urovnya arkticheskikh morey Rossii v golotsene [Holocene oscillations in the level of the Russia arctic seas]. In: Problemy paleogeografii $i$ stratigrafii pleystotsena [Problems of Pleistocene paleogeography and stratigraphy], 3. M.: Geograficheskiy fakul'tet MSU [MSU, Faculty of Geography], p. 315-320. (In Russ.). http://www.aari.ru/misc/publicat/paa/PAA-109/101-110.pdf

13. Peltier W.R. 1976. Glacial-Isostatic adjustment - II. The inverse problem. Geophysical J. of the Royal Astronomical Society, 46: 669-705.

14. Peltier W.R. 1998. Postglacial variations in the level of the sea: Implications for climate dynamics and solid-Earth geophysics. Reviews of Geophysics, 36(4): 603-689. https://doi.org/10.1029/98rg02638

15. Shepard F.P. 1969. Morskaya geologiya [Marine geology]. Leningrad: Nedra, 462 p. (In Russ.).

16. Spada G., Sabadini R., Yuen D.A, Ricard Y. 1992. Effects on postglacial rebound from the hard rheology in the transition zone. Geophysical J. International, 109(2), 683-700. doi:10,1111/j.1365-246X.1992.tb00125.x.

17. Spada G., Stocchi P. 2006. The sea level equation: Theory and numerical examples. Roma: Aracne, 96 p.

18. Spada G., Stocchi P. 2007. SELEN: A Fortran 90 program for solving the "sea-level equation". Computers and Geosciences, 33(4): 538-562. https://doi.org/10.1016/j.cageo.2006.08.006

19. Spada G., Melini D., Galassi G., Colleoni F. 2012. Modeling sea level changes and geodetic variations by glacial isostasy: the improved SELEN code. http://arxiv.org/abs/1212.5061

20. Stocchi P., Spada G. 2007. Glacio- and hydro-isostasy in the Mediterraneon Sea: Clark's zones and role of remote ice sheets. Annals of Geophysics, 50(6). https://doi.org/10.4401/ag-3054

21. Whitehouse P. 2009. Glacial isostatic adjustment and sea-level change: State of the art report. Technical Report, TR09-11. 